\title{
MENGGUGAH KEPEDULIAN SISWA TERHADAP SATWA LIAR MELALUI PENDIDIKAN IPA DI SEKOLAH DASAR
}

\author{
H. Dede Margo Irianto*)
}

\begin{abstract}
Abstrak
Kepedulian terhadap satwa liar ini harus ditanamkan sejak dini, agar dalam setiap gerak kehidupan sesuai dengan perkembangan usia manusia, mereka selalu menaruh perhatian terhadap satwa liar dalam bentuk tindakan kongkrit, yang dapat ikut mencegah kepunahan satwa liar. Penanam kepedulian terhadap satwa liar sejak usia dini dapat dilakukan dengan berbagai cara. Salah satu cara yang menurut penulis tepat adalah dengan pendidikan, khususnya melalui pendidikan IPA di sekolah dasar.

Pendidikan IPA di Sekolah Dasar dapat digunakan untuk menanamkan kepedulian siswa terhadap satwa liar sejak dini. Kepedulian terhadap satwa liar tersebut dapat dimasukkan dalam bahan ajar yang menyangkut tentang Makhluk hidup dan proses kehidupannya, yaitu manusia, hewan, tumbuhan, dan interaksinya. Permasalahannya adalah, tindakan konkrit apa yang harus dilakukan oleh para praktisi pendidikan dalam melaksanakan kegiatan pembelajaran IPA di sekolah dasar, dalam materi-materi terkait, sehingga dapat menanamkan kepedulian siswa terhadap satwa liar sejak usia dini.
\end{abstract}

\section{Kata Kunci : Kepedulian Siswa, Satwa Liar, Pendidikan IPA, Sekolah Dasar}

\section{A. PENDAHULUAN}

World Conservation Monitoring Committee (1994) melaporkan kekayaan bumi Indonesia di bidang keanekaragaman hayati diantaranya mencakup sekitar 27.500 species tumbuhan berbunga (merupakan $10 \%$ dari seluruh species tumbuhan yang ada di dunia, 1539 species burung (merupakan $17 \%$ dari seluruh species burung yang ada di dunia), 515 species reptilia (merupakan $16 \%$ dari seluruh species reptilia yang ada di dunia). Potensi keanekaragaman hayati tersebut didukung pula oleh adanya kawasan hutan yang mencakup sekitar 109,02 juta hektar hutan yang terdiri dari hutan konservasi 17,91 hektar, hutan lindung 34,01 hektar, hutan produksi 61,90 hektar, dan hutan konversi untuk berbagai penggunaan lain seluas 35,20 hektar.

Kondisi obyektif yang kita hadapi sekarang menunjukkan bahwa Indonesia selain dikenal sebagai Negara mega keanekaragaman hayati, juga dikenal sebagai Negara dengan laju pengurangan luas hutan alam yang terbesar didunia. Data menunjukkan, laju pengurangan luas hutan tersebut di pulau Sumatera mencapai 2\% per tahun, di pulau Jawa mencapai 0,42 \% per tahun, di pulau Kalimantan mencapai 0,94\% pertahun, di pulau Sulawesi mencapai $1 \%$ pertahun, dan di Irian Jaya mencapai 0,7 \% per tahun. (Dirjen Perlindungan Hutan dan Konservasi Alam, 2001). 
Angka laju pengurangan hutan yang cukup besar, selain berdampak merugikan dalam banyak hal juga merupakan sesuatu yang sangat merugikan bagi keberadaan satwa liar di Indonesia. Pengurangan luas hutan berakibat berkurangnya luas habitat yang dapat dihuni oleh satwa liar, hal ini akan menyebabkan keberadaan mereka menjadi terancam. Bukan tidak mungkin dengan terus berlangsungnya kerusakan hutan lama kelamaan jumlah satwa liar yang mengalami kepunahan akan semakin bertambah. Untuk itulah, maka diperlukan adanya perhatian dan kepedulian dari semua pihak agar hal tersebut tidak terjadi di negeri tercinta ini.

Kepedulian terhadap satwa liar ini harus ditanamkan sejak dini, agar dalam setiap gerak kehidupan sesuai dengan perkembangan usia manusia, mereka selalu menaruh perhatian terhadap satwa liar dalam bentuk tindakan kongkrit, yang dapat ikut mencegah kepunahan satwa liar. Penanam kepedulian terhadap satwa liar sejak usia dini dapat dilakukan dengan berbagai cara. Salah satu cara yang menurut penulis tepat adalah dengan pendidikan, khususnya melalui pendidikan IPA di sekolah dasar.

Mengapa Pendidikan IPA di sekolah dasar yang dijadikan sarana untuk menanamkan kepedulian terhadap satwa liar? Ada beberapa alasan yang dapat dikemukakan, diantaranya : 1) Mata pelajaran IPA di sekolah dasar bertujuan agar siswa : mempunyai minat mempelajari alam sekitar, mencintai alam sekitar, serta menyadari kebesaran dan keagungan Tuhan (depdikbud, 1994); 2) Rutherford dan Ahlgren (1990) mengemukakan bahwa sains dapat memberi seseorang pengetahuan tentang lingkungan biofisik dan perilkau ssosial yang diperlukan untuk pengembangan pemecahan yang efektip bagi masalah local dan global. 3) Sukarno, dkk mengatakan bahwa pendidikan IPA harus mampu memberikan pengetahuan kepada siswa tentang dunia dimana kita hidup, dan bagaimana kita sebagai makhluk hidup harus bersikap terhadap alam sekitarnya. Untuk itulah, penulis mencoba mengemukakan tulisan sederhana dengan judul menggugah kepedulian siswa terhadap satwa liar melalui pendidikan IPA di Sekolah Dasar.

\section{B. PENDIDIKAN IPA DI SEKOLAH DASAR}

Para akhli pendidikan sains di Negara-negara maju secara intensif menekankan pentingnya pemerintah menyusun kurikulum yang dapat melibatkan anak sejak dini kedalam kegiatan sains. Menurut mereka hal itu perlu dilakukan karena kurikulum yang demikian dapat mempersiapkan dan menjadikan warga Negara yang melek sains dan teknologi, mampu menghadapi kehidupan yang makin kompetitip serta mampu memilih dan mengolah informasi untuk digunakan sebagai dasar pengambilan keputusan dalam kehidupan sehari-hari. 
National Science Teacher Association (NSTA), misalnya mencanangkan empat tujuan utama pendidikan sains yang meliputi : Personal needs, menyiapkan individu yang mampu menggunakan sains bagi peningkatan tarap hidup dan menghadapi perkembangan teknologi; Social Issues, menanamkan tanggung jawab terhadap isu-isu yang berkaitan dengan sains di masyarakat; Career Education Awareness, menanamkan kesadaran akan akan sifat dan ruang lingkup sains yang berhubungan dengan pekerjaan serta pengembangan minat dan bakat; dan AcademicPreparation, memberi landasan bagi siswa yang akan mendalam sains secara akademik dan professional (Connor, 1990)

Di Indonesia, fungsi pendidikan IPA di Sekolah Dasar (GBPP IPA SD, 1994) diantaranya adalah : Mengembangkan pengetahuan tentang pelbagai jenis dan perangai lingkungan alam dan lingkungan buatan dalam kaitannya dengan pemanfaatannya bagi kehidupan sehari-hari, mengembangkan kesadaran tentang adanya hubungan keterkaitan yang saling mempengaruhi antara kemajuan IPA dan Teknologi dengan keadaan lingkungan dan pemanfaatannya dalam kehidupan sehari-hari.; Sedangkan tujuan pendidikan IPA di sekolah Dasar, diantaranya adalah : Siswa mempunyai minat untuk mengenal dan mempelajari benda-benda serta kejadian di lingkungan sekitar, dan mengenal serta memupuk rasa cinta terhadap alam sekitar, sehingga menyadari kebesaran dan keagungan Tuhan Yang Maha Esa.

Ruang lingkup, mata pelajaran IPA mencakup 1) makhluk hidup dan proses kehidupannya, yaitu manusia, hewan, tumbuhan, dan interaksinya, 2) materi, sifat-sifat, dan kegunaannya meliputi : udara, tanah, air, dan batuan 3) listrik dan magnet, energi dan panas, gaya dan pesawat sederhana, cahaya dan bunyi, tata surya, bumi, dan benda-benda langit lainnya 4) kesehatan, makanan, penyakit, dan pencegahannya, dan 5) sumber daya alam, kegunaan, pemeliharaan dan pelestariannya.

Dari uraian di atas nampak bahwa Pendidikan IPA di Sekolah Dasar dapat digunakan untuk menanamkan kepedulian siswa terhadap satwa liar sejak dini. Kepedulian terhadap satwa liar tersebut dapat dimasukkan dalam bahan ajar yang menyangkut tentang Makhluk hidup dan proses kehidupannya, yaitu manusia, hewan, tumbuhan, dan interaksinya.

Permasalahannya adalah, tindakan konkrit apa yang harus dilakukan oleh para praktisi pendidikan dalam melaksanakan kegiatan pembelajaran IPA di sekolah dasar, dalam materi-materi terkait, sehingga dapat menanamkan kepedulian siswa terhadap satwa liar sejak usia dini.

\section{TINDAKAN-TINDAKAN YANG DAPAT DILAKUKAN}

1. Memilih pendekatan dan metode yang tepat dalam kegiatan pembelajaran pada materi-materi terkait 
Pemilihan pendekatan dan metode yang tepat, merupakan langkah pertama yang penting untuk dilakukan dalam menanamkan kepedulian terhadap satwa liar sejak dini kepada siswa Sekolah Dasar.

Salah satu pendekatan yang layak digunakan adalah pendekatan keterampilan proses. Mengapa pendekatan keterampilan proses? Pendekatan keterampilan proses adalah cara memandang anak didik sebagai totalitas manusia yang diimplementasikan dalam kegiatan belajar mengajar dengan memperhatikan pengembangan pengetahuan, sikap, dan nilai serta keterampilan (Karso, 1993). Melalui keterampilan proses , siswa dilatih dan dirangsang untuk selalu bertanya, berpikir kritis, obyektip, serta terbiasa mengupayakan kemungkinan-kemungkinan jawaban terhadap suatu masalah. Keterampilan proses bermanfaat sebagai cara memecahkan masalah yang dihadapi dalam kehidupan yang relevan.

Dengan keterampilan proses yang dimilikinya, siswa dapat mengambil sikap konkrit terhadap apa yang dapat diamati dari lingkungan sekitarnya, termasuk diantaranya adalah keberadaan satwa liar. Melalui aplikasi konsep - konsep IPA tentang saling ketergantungan antar ,makhluk hidup, dikaitkan dengan keberadaan satwa liar, siswa diharapkan dapat memiliki kepedulian terhadap satwa liar tersebut, melalui tindakan nyata.

2. Melakukan kegiatan kunjungan ke obyek-obyek terkait secara berkala dan berkesinambungan

Untuk membuat siswa memahami kondisi satwa liar dialam , dan permasalahanpermasalahan yang dihadapi, maka secara berkala siswa perlu diajak untuk mengunjungi obyek-obyek terkait. Misalnya kunjungan dapat dilakukan terhadap tempat-tempat yang ada di dekat tempat tinggal siswa, seperti kebun binatang, Taman Hutan Raya, dan tempat lainnya.

Dalam pelaksanaan pembelajaran materi terkait, guru bisa saja secara langsung melaksanakan kegiatan pembelajaran di luar kelas, yaitu di tempat sekitar sekolah yang dapat memancing pertanyaan siswa terhadap keberadaan satwa liar di alam.

3. Mengadakan kegiatan-kegiatan yang relevan.

Kegiatan dimaksud, misalnya adalah lomba mengarang tentang keberadaan satwa liar di alam dan cara melestarikannya; lomba menggambar satwa liar, serta mengadakan pemutaran film tentang satwa liar baik itu film produksi Indonesia, maupun film produksi luar negeri.

4. Melakukan Penilaian yang komprehensip dan utuh.

Untuk menanamkan dan memelihara kepedulian siswa terhadap satwa liar, maka yang juga harus diperhatikan dalam kegiatan pembelajaran pendidikan IPA pada materi terkait adalah system penilaian. 
Sistem penilaian yang digunakan tidak boleh hanya bersifat kognitp semata-mata, tetapi juga tidak boleh dilupakan penilaian yang bersifat afektip dan psikomotor. Artinya, penilaian juga dilakukan terhadap sikap yang ditunjukkan oleh siswa terhadap satwa liar, dan kalau memungkinkan juga dilakukan penilaian terhadap perfoman / untuk kerja siswa dalam memelihara satwa liar.

\section{PENUTUP}

Demikianlah tulisan singkat dan sederhana ini dibuat, dengan harapan dapat dijadikan sebagai titik tolak untuk membuat tulisan berikutnya yang bersifat lebih operasional dan konkrit. Terutama dalam kaitannya dengan pelaksanaan kegiatan pembelajaran IPA di sekolah dasar pada materi-materi terkait, yang diharapkan dapat menanamkan kepedulian terhadap satwa liar di lingkungan sekitar mereka.

\section{DAFTAR PUSTAKA}

Connor, J.V. (1990). Naïve Conceptions and The School Science curriculum, dalam Rowe, M.B. (eds) 1990. What Research Says to The Science Teacher : The Process of Knowing, Washington National Science Teacher Association.

Depdikbud, (1994). Kurikulum Pendidikan Dasar, Landasan, Program, dan

Pengembangan. Jakarta : Depdikbud.

Depdikbud, (1994). Kurikulum Pendidikan Dasar, Garis-Garis Besar Program Pengajaran (GBPP). Jakarta : Depdikbud.

Sukarno. (1973). Dasar - Dasar Pendidikan Science. Jakarta : Bhatara

Dirjen Perlindungan Hutan dan Konservasi Alam. Pengelolaan Kawasan Konservasi

Dalam Era Otonomi Daerah. Dirjen PerlindunganHutan dan Konservasi Alam : Direktur Konservasi Kawasan.

*) H. Dede Margo Irianto adalah dosen UPI Kampus Cibiru 